\title{
THE EFFECTS OF FISCAL POLICY SHOCKS ON THE BUSINESS ENVIRONMENT
}

\author{
Gabriela DOBROTĂ (D $1^{*}$, Alina Daniela VODA (D)2, \\ Dănuț Dumitru DUMITRAȘCU(iD) 3
}

${ }^{1}$ Faculty of Economics, Constantin Brâncusi University of Targu-Jiu, Targu-Jiu, Romania

${ }^{2}$ Faculty of Economics, Lucian Blaga University of Sibiu, Sibiu, Romania

${ }^{3}$ Faculty of Engineering, Lucian Blaga University of Sibiu, Sibiu, Romania

Received 09 July 2020; accepted 18 March 2021

\begin{abstract}
Fiscal policy influences economic conditions through public spending and taxes, generating positive or negative impulses, both on short and long term. The present research focuses on analysing the effects of the discretionary changes in the fiscal policy in seven post-communist countries of the European Union during the period 2000-2018. The autoregressive distributed lag model (ARDL) has been applied in order to obtain the convergence rates to equilibrium with a clear analysis of the periods needed to achieve the long-run fiscal sustainability. Also, the error correction vector model (VECM), which is based on the autoregressive vector (VAR) model, has been used in the second part of the analysis focusing on the Cholesky factorization of innovations. Impulse-response functions aiming to estimate the response of government expenditures to the shock produced by three macroeconomic variables have been identified.
\end{abstract}

Keywords: fiscal policy, business environment, autoregressive distributed lag model, macroeconomic variables, impulse response function, convergence rates.

JEL Classification: E62, E63 C32, H30.

\section{Introduction}

Fiscal policy is an important component of macroeconomic policy. The state can use the tools that it provides to restore economic balance, along with government spending. At the macroeconomic level, it must be anchored in the reality of the business environment, any faulty decision causing negative impulses on the economy, being a source of uncertainty for firms for several reasons (Anzuini et al., 2020). Fiscal policy must be correlated with the economic cycle, because economic activity cannot be linear. According to the Keynesian theory, the application of countercyclical fiscal policies is a measure that can have beneficial effects on the whole economy during periods of recession, and contributing to the stabilization

${ }^{\star}$ Corresponding author. E-mail: gabi.dobrota70@gmail.com

Copyright (c) 2021 The Author(s). Published by Vilnius Gediminas Technical University

This is an Open Access article distributed under the terms of the Creative Commons Attribution License (http://creativecommons. org/licenses/by/4.0/), which permits unrestricted use, distribution, and reproduction in any medium, provided the original author and source are credited. 
of output in the business cycle (O'Sullivan \& Sheffrin, 2003), government expenditure and taxes being useful tools to stimulate the economic activity (Munir \& Riaz, 2019). Thus, the government should intervene in recessions and depressions through monetary and fiscal policy (Blinder, 2017). From the perspective of the Austrian School of Economics, fiscal policy has no impact on the economic cycle and government intervention can exacerbate economic distortions. However, regardless of the arguments of a current or another, most of economists believe that tax reduction has a positive influence on economy (Ferede \& Dahlby, 2016; Arnold et al., 2011). This study is based on the hypothesis that government expenditure plays a strategic role in implementing fiscal policy and ensuring long-run fiscal sustainability. The sustainability is ensured insofar as the economic environment is not affected by the fiscal policy measures. The research was conducted based on the analysis of data from seven countries (Bulgaria, Czech Republic, Estonia, Hungary, Latvia, Poland and Romania), selected according to geographical criteria and the recent common historical past (former communist countries), which have undergone institutional reforms during the transition from the communist regime to the market economy and have common features that provide the opportunity to analyse the determinants with positive or negative effects on the economic environment. In the context of the specified aspects, this paper aims to identify the convergence rates to equilibrium using the ARDL model, as well as the gross domestic product (GDP), tax revenues and public debt shocks on the government expenditure by building the VECM model, based on the Cholesky decomposition. The model was built using quarterly data, as it provides a better opportunity to identify the government expenditure responses to the change with a standard deviation of the exogenous variables shock. Within the present study we will consider two hypotheses that represent the starting point of this empirical analysis. According to the first hypothesis, government spending plays a strategic role in the implementation of fiscal policy and on the insurance of long-term fiscal sustainability. The second hypothesis is closely correlated with the first, because the application of fiscal policy in Eastern European countries does not have an ameliorating effect on fiscal shocks and, implicitly, government spending as a tool in economic balancing, cannot have satisfactory results. In support of these hypotheses or in their rejection, scientific testing methods will be applied that will help to establish the final conclusions and representation of the particularities of the fiscal policies applied in the specific geopolitical context for the analysed countries. Using a data set for the period 2000-2018, was made not only an estimation of the elasticity of long-term government spending and convergence rates at equilibrium, but also an estimate of the impulse-response functions thus highlighting the shocks exercised by the exogenous variables analysed on the government expenditure, taking into account the interactions between the data series.

In this context, the rest of the paper is further structured as follows: Section 1 Review of the literature, which performs a brief critical approach of the existing studies in the field of the approached issue; Section 2 Research Methodology; Section 3 Empirical results and discussions, obtained by processing the collected data and their interpretation. Finally, the conclusions drawn from the conducted study, placed in the context of the existing literature, as well as the limits of the research and future directions to be explored have been systematized. 


\section{Review of literature}

The applied tax policy has always generated controversy, the effects it produces on the business environment being different, in accordance with the economic background. The fiscal measures have long-run effects depending on the moment and circumstances of adoption. A realistic hypothesis is invoked by Downs (1957) who noted that parties in power "formulated policies in order to win the election instead of winning elections to formulate policies", drawing the attention to the fact that there is the possibility of adopting beneficial measures for a state only that they are conditioned by those they are governed by. Various studies have shown a correlation between economic development and indicators related to the government revenue and government expenditure, more precisely the fiscal and budgetary policy, fiscal multipliers being considered the determinants of the GDP (Romer, 2011). An analysis of the impulse-response functions using the VAR method was conducted by Perotti (2004) which studied the effects of fiscal policy on GDP, inflation and interest rates in five OECD countries. Afonso and Sousa (2009) investigated the macroeconomic effects of the fiscal policy using the Structural Vector Bayesian Autoregressive model, demonstrating that the shock of government spending has a low effect on the GDP while Peren Arin et al. (2019) identify a robust positive effect of productive spending on economic growth.

Also, other study for the Eurozone countries in the period 2000-2016 (Afonso \& Leal, 2019), showed that the government expenditure had a positive effect on output while the tax multipliers presented negative signs. Mirdala (2009) investigates the fiscal policy shocks by estimating VAR in six emerging countries from 2000 to 2008. The results were contradictory, because the fiscal policies applied in different countries to mitigate the negative effects generated by the 2008 economic crisis, have determined a weak correlation between the shocks produced by the fiscal policy and the economic variables (Boiciuc, 2015). Jordà and Taylor (2015) stated that, after a global financial crisis, a controversial race of fiscal austerity followed in many countries, pointing out that it is always a blow to economic growth. Salto (2016) sought to identify the best fiscal policies in an environment affected by the economic crisis. Akerlof et al. (2014) considered that only way to combat the effects of the economic crisis is to revolutionize the defective macroeconomic policies. Other studies have attempted to identify whether the fiscal policy response function is still an important element after the Great Recession (Golinelli et al., 2018). Pontus (2016) and Stockhammer et al. (2016) analysed the size of the fiscal multipliers in different states. The effects of fiscal policies were also analysedon a meta-regression basis by Gechert (2015) and Heinemann et al. (2018). Tabellini (2016) considers that countries should give up to the sovereignty over a part of their tax revenues and transfer them to the euro area. Other different studies show the implications of institutions for coordinating fiscal policies at national level (Ban, 2014; Bodea \& Higashijima, 2017). Teles and Mussolini (2014), Bhandari et al. (2017) and Leeper (2017) referred to a number of macroeconomic indicators which must be taken into account in order to analyse their response to fiscal policies. Cordes et al. (2015) assert that a better management of government expenditure may be possible based on the existence of a public financial management. The results of a study show a cumulative, slightly positive effect on the GDP of Germany in the years of recession, while fiscal measures were more or less neu- 
tral in euro area (Gadatsch et al., 2016). The Cointegrated Vector Autoregressive model was also used to highlight the relationship between aid and internal fiscal aggregates, with fiscal reforms having positive effects on expenditure management (Bwire et al., 2017). Critical approaches related to the Keynesian theory of the fiscal policy application are found in the works of Palley (2015) and Johannsen (2014). Other aspects that capture the variation of the different economic indicators in response to the policies for the economic development of a state were analysed by Mertens and Ravn (2014) and Bova et al. (2014).

\section{The research methodology}

The fiscal policy applied by the government can have both positive and negative effects on the individuals and businesses. Thus, in accordance with Perotti R. (2004), based on the paper of Blanchard and Perotti (1999), who stated that "government spending shocks as having a positive effect on output, and positive tax shocks as having a negative effect", this paper analyses the effects of exogenous variables on government expenditure. The application of mixed research methods represents an approach of the present study that combines and associates both quantitative and qualitative forms. The paper involves the use of both approaches in tandem so that the ability of the analysis to present a clear picture of the study is as strong as possible (Creswell \& Plano Clark, 2017).

\subsection{The autoregressive distributed lag model (ARDL)}

The autoregressive distributed lag model (ARDL) was applied to evaluate the effects of shortrun fiscal policy on long-run fiscal sustainability. The first step in performing the analysis involves testing the unit roots of the time series. The Augmented Dikey-Fuller (ADF) test was used to verify stationarity and the Phillips-Perron test as an extension, to confirm the hypotheses, the information being found in Table 1. Thus, the stochastic process will take the following form:

$$
y_{t}=\phi y_{t-1}+\varepsilon_{t}
$$

where: $|\phi| \leq 1$ and $\varepsilon$ reprezent the white noise, and $y_{i}$ time series. The condition for which the time series $y_{i}$ can be stationary is as $|\phi| \leq 1$. If $|\phi|=1$, the time series has a unit root, which implies an absence of stationarity.

Taking into account the aspects identified by Hamilton (1994), the ADF test involves estimating the following equation by applying the first difference:

$$
\Delta y_{t}=\left(\phi_{t-1}\right) y_{t}+\sum_{j=1}^{p} \phi_{j}\left(\Delta y_{t-j}\right)+\varepsilon_{t}, ; t=1,
$$

where: $\Delta$ is the difference operator, $t$ is the time trend, $p$ measures the lag length of the dependent variable $\Delta y_{t}$ and $\phi$ represents the parameters to be estimated. Following the implementation of the stochastic process, the time series will become stationary by rejecting the alternative hypothesis according to which the variable has a unit root and accepting the alternative hypothesis. 
The research methodology used is the autoregressive distributed lag model. ARDL $(p, q)$ is the regression of the least squares where $p$ represents the lags of the dependent variable and $q$ the independent variables. This model was also applied in the papers written by Aderemi et al. (2019), Özer and Karagöl (2018) as it allows the use of stationary time series at level $\mathrm{I}(0)$, first difference $\mathrm{I}(1)$, as well as in a mix between the two. In the present study, some models imposed the use of time series in the first difference, and some a mix between I (0) and I (1). Considering the general ARDL model proposed by Pesaran and Shin (1998), it can be found in the following form:

$$
y_{t}=\alpha_{0}+\alpha_{1} t+\sum_{i=1}^{p} \phi_{i} y_{t-1}+\beta^{\prime} x_{t}+\sum_{i=0}^{q-1} \beta_{i}^{* \prime} \Delta x_{t-i}+\mu_{t}
$$

where: $a_{0}, a_{1}, \beta, \beta_{1}, \beta_{q-1}$ and $\phi_{i}$ are the short-run parameters of the least square regression, and $\mu_{t}$ is the error term.

$$
\Delta x_{t}=P_{1} \Delta x_{t-1}+P_{2} \Delta x_{t-2}+\ldots+P_{n} \Delta x_{t-n}+\varepsilon_{t},
$$

where: $x_{t}$ are $k$-dimensional variables $I(1)$ that are not cointegrated, $\varepsilon_{t}$ are uncorrelated serial disturbances with zero mean and constant variance - covariance, and $P_{i}$ are coefficient matrix $(k \times k)$ so that the process of the autoregressive vector is stable in $\Delta x_{t}$. Moreover, this model requires that the roots of the expression $1-\sum_{i=1}^{p} \phi_{i} z^{i}=0$ to lie outside the unit circle and that there is only one long-run stable link between $y_{t}$ and $x_{t}$.

We consider the following four variables: government expenditure $g_{t}$, GDP (value of production) $x_{t}$, tax revenues (total tax receipts and social contributions) $t_{t}$, government debt $\pi_{t}$. The dependent variable of the distributed lags will be predicted by the independent variables of the distributed lags by the following function:

$$
\ln g_{t}=\Delta \ln g_{t-i}+\Delta \ln x_{t-i}+\Delta \ln t_{t-i}+\Delta \ln \pi_{t-i}+\mu_{t}
$$

where: $\Delta$ represents the first difference, ln natural logarithm and $\mu_{t}$ the error term. Gonzalo (1994) identified alternative methods of estimating the long-run equilibrium relationship. The mathematical representation of the estimated long-run relationship within the ARDL model can be written as follows:

$$
\ln g_{t}=\alpha_{0}+\sum_{i=1}^{k} \beta_{1} \Delta \ln g_{t-1}+\sum_{i=1}^{k} \beta_{2} \Delta \ln x_{t-i}+\sum_{i=1}^{k} \beta_{3} \Delta \ln t_{t-i}+\sum_{i=1}^{k} \beta_{4} \Delta \ln \pi_{t-i}+\mu_{t},
$$

where: $\beta_{i}$ represents the long-run relationship between model variables based on an optimal maximum number of lags indicated by the selection criteria. Next, the short-run relationship required to identify the rate of convergence to equilibrium will be estimated, receiving the following form:

$$
\ln g_{t}=\alpha_{1}+\sum_{i=1}^{k} \varphi_{1} \Delta \ln g_{t-i}+\sum_{i=1}^{k} \varphi_{2} \Delta \ln x_{t-i}+\sum_{i=1}^{k} \varphi_{3} \Delta \ln t_{t-i}+\sum_{i=1}^{k} \varphi_{4} \Delta \ln \pi_{t-i}+\Omega E C T_{t-1}+\mu_{t},(7)
$$


where: $\alpha_{1}$ is constant, the symbols $\varphi_{1} \ldots \varphi_{4}$ represent the short-run relationship between the variables, $E C T_{t-1}$ is the error correction term that measures the speed of adjustment to equilibrium and $\mu_{t}$ represents the white noise. Thus, the long-run elasticity of government expenditure and rates of convergence to equilibrium can be estimated and evaluated by applying the ARDL model.

\subsection{The analysis of the VAR process}

Since this research is based on mixed methods of analysis, the autoregressive vector model is used as an extension to demonstrate its robustness. This model is used in multivariate time series analysis and can be applied when all the reference variables are stationary. Suppose we consider the four exogenous variables, the mathematical representation of the VAR model can be written as follows:

$$
\begin{aligned}
& g_{t}=v_{1}+A_{1} g_{t-1}+A_{1} t_{t-1}+A_{1} x_{t-1}+A_{1} \pi_{t-1}+\varepsilon_{t} \\
& t_{t}=v_{2}+A_{2} g_{t-1}+A_{2} t_{t-1}+A_{2} x_{t-1}+A_{2} \pi_{t-1}+\varepsilon_{t} ; \\
& x_{t}=v_{3}+A_{3} g_{t-1}+A_{3} t_{t-1}+A_{3} x_{t-1}+A_{3} \pi_{t-1}+\varepsilon_{t} ; \\
& \pi_{t}=v_{4}+A_{4} g_{t-1}+A_{4} t_{t-1}+A_{4} x_{t-1}+A_{4} \pi_{t-1}+\varepsilon_{t}
\end{aligned}
$$

To extrapolate the above representations, the VAR model will take the following form:

$$
A_{0} y_{t}=v+\sum_{i=1}^{p} A_{i} y_{t-i}+\varepsilon_{t} \text {, }
$$

where: $A_{0}$ represents the contemporaneous invertible matrix of the present model; the vector $y_{t}$ capitalizes all the variables in the model at a time $t$, more precisely $y_{t} \equiv\left[\begin{array}{llll}g_{t} & t_{t} & x_{t} & \pi_{t}\end{array}\right]$, and $v$ is the intercept vector; $A_{i}(i=1,2, \ldots, p)$ represents the coefficient matrices $k \times k, p$ is the lag length and $\varepsilon_{t}$ the vector of structural shocks.

The reduced form corresponding to Eq. (8) is determined by multiplying both sides of this with the inverse matrix $A_{0}^{-1}$, as follows:

$$
y_{t}=v+\sum_{i=1}^{p} B_{i} y_{t-i}+u_{t},
$$

where: $B_{i}=A_{0}^{-1} A_{i}$ and $u_{t}=A_{0}^{-1} \varepsilon_{t}$, thus, we will define $B(L) y_{t}=u_{t}$ which is a matrix of $L$ lag length $L\left(L^{i} y_{t}=y_{t-i}\right)$, intended to capture the dynamics of the system. If the number of lags is unknown, it can be determined by studying the adjusted R-squared indicator of each equation. In addition, this matrix allows studying the incidence of a shock on the progress of the dependent variable, expressing the impulse-response functions of the shocks to the elements of $y_{t}$. It is necessary to accept the probability that $y_{t}$ satisfies the condition identified by Cavaliere et al. (2012) whereby this vector is cointegrated with $r$ cointegration relations, whereas $I(1, r)$. However, the existence of a cointegration relationship implies the 
combination of the VAR model with the error correction model, which becomes the vector error correction model (VECM). Moreover, the derived model implies the use of stationary variables at the same level. The panel vector error correction model applied to the seven countries in the analysis, as well as the vector error correction model applied to Romania, will allow the estimation of the impulse-response functions in order to identify the shocks that the exogenous variables produce on government expenditure. These kinds of "panel" econometric models allow the study of both time series and cross-sectional data. The analysis of the multidimensional time series will make it possible to identify a correlation between the variables of interest.

In order to evaluate the effects of fiscal policy, shocks at the level of the selected countries were identified. Therefore, to specify the equation of the effect of the fiscal policies, we will start with a simple linear function, as follows:

$$
y=f(X)
$$

where: $y$ is represented by government expenditure, and $X$ by total variables of the model (TVM). The construction of the model starts by assuming that the variables are associated with a possible mathematical form, which represents the relationship between government expenditure and the total variables of the model, receiving the following form:

$$
y_{t i}=\tau_{0}+\tau \cdot T V M_{t} .
$$

In this equation $\tau>0$ and $\tau_{0}$ is the free term of the linear function.

Equation (14) can be expressed as a simple linear equation model, as follows:

$$
y_{t i}=\tau_{0}+\tau_{1} \cdot g_{t}+\tau_{2} \cdot x_{t}+\tau_{3} \cdot t_{t}+\tau_{3} \cdot \pi_{t}+\varepsilon_{t}
$$

where: $\varepsilon_{t}$ is the residual term (white noise).

Equation (15) is the basic model for analysing the effects of exogenous variables on government expenditure. Further on, the analysis process involves identifying the time series cointegration relationships. This is based on the arguments made by Engle and Granger (1987) in which cointegration involves estimating the long-run equilibrium of non-stationary time series with infinite variance, assuming that its deviation from equilibrium is stationary with finite variance. Specifically, the existence of cointegration can only be validated if the time series used in an econometric model become stationary after the first difference is applied, but a specific linear combination of them is at stationary level. The inclusion of the cointegration analysis in the vector autoregressive models was performed by Johansen (1988, 1991), demonstrating that it can be tested in the form of a hypothesis in the vector error correction model.

$$
\Delta_{y t}=v+\alpha \beta^{\prime} y_{t-1}+\Gamma_{1} \Delta g_{t-1}+\Gamma_{2} \Delta x_{t-1}+\Gamma_{3} \Delta t_{t-1}+\Gamma_{4-1} \Delta \pi_{t-4+1}+\varepsilon_{t},
$$

where: $\Delta$ is the difference operator, $v$ is the intercept vector, $\alpha$ is the adjustment matrix $k \times r$ and $\beta$ is the matrix containing the long-run parameters $k \times r$, more precisely the linear cointegration relations $r$. The matrix with the order coefficients $k \times k$ is found in the equation in the form $\Gamma_{i}$, where $i=1,2, \ldots p-1$. 
The reduced form of the VECM model can be identified as follows:

$$
\Gamma_{0} \Delta y_{t}=v+\Pi y_{t-1}+\sum_{i=1}^{p-1} \Gamma_{i} \Delta y_{t-1}+\varepsilon_{t} .
$$

Equations (16) and (17) synthesize the inter-temporal relationships between the variables of the model, being difficult to identify them only on the basis of the coefficients of the equations. Applying the impulse-response functions will make it possible to represent the response of the endogenous variable to the shock produced by the exogenous variables. Usman et al. (2017) and Benkwitz et al. (2001) exemplify the mathematical estimation of the impulse-response function in the VECM model, which is also applied in the case of the present analysis, due to the existence of cointegration relationships. Thus, the Eqs (12) and (17) are the basis of the application of the impulse-response function, which can be found in the following form:

$$
\phi_{g y, t}=\phi_{g y, t}\left(A_{0}, A_{1}, \ldots, A_{p}\right)=\phi_{g y, t}\left(\alpha, \beta, \Gamma_{0}, \Gamma_{1}, \ldots, \Gamma_{p-1}\right) .
$$

The variable response $g$ to a shock produced by the variables capitalized by $y$ over a period of time $t$ is represented by $\phi_{g y, t}$, and $\alpha, \beta, \Gamma_{0}, \Gamma_{1}, \ldots, \Gamma_{p-1}$ define the matrices parameters of the VECM model.

\section{Empirical results and discussions}

Within the present study, the ARDL and panel VECM methods were applied, taking into account four variables aiming to create an overview with regard to fiscal sustainability in seven post-communist countries from Eastern Europe. In order to analyse the effects of fiscal policy, the quarterly time series of government expenditure (GE), GDP, tax revenue (GR) and government debt (GD), from 2000:1-2018:4, were used. The total number of observations for each data series is 76 . Due to the influence of the specific seasonality of government debt, the adjustment procedure was applied using TRAMOSEATS. All variables are expressed in real terms using the GDP deflator. The data was also expressed in logarithms for the model construction. The use of time series data to estimate the parameters of the economic relationship between the variables is based on several assumptions, one of which is being that such data series is stationary. In this context, the testing for stationarity of the used data series becomes essential to this analysis. The Augmented Dickey-Fuller (ADF) and Phillips-Perron (PP) tests were used for identifying the existence of unit roots of the dates using interception. The variables becoming stationary at level or by applying the first difference. The reason why some variables are not stationary is represented by their critical values which are smaller than the statistical test in absolute value at a significance level of 1 per cent. However, most of the variables considered became stationary after the first difference, with the exception of certain variables of the models proposed for the Czech Republic, Hungary and Poland. The results show that the series are integrated by different orders I (0) and I (1). 
Therefore, the variables are suitable for the analytical purpose for which they were collected. Appropriate modelling techniques for analysis construction were established after identifying the optimal number of lags taking into account the specification of sequential modified LR test statistic (LR), Final prediction error (FPE), Akaike information criterion (AIC), Schwartz information criterion (SC) and Hannan-Quinn information criterion (HQ) from Table 1.

Table 1. Lag order selection criteria (source: own data processing)

\begin{tabular}{|l|c|c|c|c|c|c|}
\hline \multirow{2}{*}{ Country } & \multicolumn{5}{|c|}{ Number of lags } & \multirow{2}{*}{$\begin{array}{c}\text { Selected } \\
\text { Lag }\end{array}$} \\
\cline { 2 - 6 } & LR & FPE & AIC & SC & HQ & 5 \\
\hline Bulgaria & 5 & 5 & 5 & 1 & 1 & 2 \\
\hline Czech Republic & 6 & 2 & 6 & 1 & 2 & 5 \\
\hline Estonia & 5 & 5 & 6 & 1 & 1 & 5 \\
\hline Hungary & 5 & 2 & 2 & 1 & 2 & 2 \\
\hline Latvia & 4 & 2 & 2 & 1 & 1 & 1 \\
\hline Poland & 7 & 2 & 7 & 1 & 1 & 10 \\
\hline Romania & 10 & 10 & 10 & 1 & 10 & \\
\hline
\end{tabular}

The optimal number of lags that had a repetitive character was selected for modelling. Akaike information criterion and Final prediction error are the most used selection criteria, minimizing the chances of underestimation and maximizing the chance of recovering the true length of the lag (Liew, 2004). In the present study, only the model of Hungary represents an exception, the number of lags being chosen based on the sequential modified LR test statistic criterion. The main argument for choosing this selection criterion is given by the stability of the model which will be further demonstrated. Although the variables expressed were stationary at level or by applying the first difference, we proceeded to construct the ARDL models that allow their use even if these variables are purely $\mathrm{I}(0)$, purely $\mathrm{I}(1)$ or a mix. The validity of the models is satisfied by observing four conditions: the correct representation of the model by choosing the optimal number of lags, the lack of autocorrelation, the normalization and the lack of homoskedasticity of the residuals. The variable systems of the economies in the countries included in this analysis fulfil the conditions regarding the quality of the residuals, except for a small proportion, more precisely, of a model where there are signs of lack of normality. The analysis confirmed the stability of the ARDL models by applying two different stability tests CUSUM (Cumulative Sum Control Chart) test shown in Figure 1, as well as the CUSUM of Squares test presented in Figure 2. Diagnostic analyses determine the stability of the models at a significance level of 5 per cent. The parameter variables are stable with small changes in the CUSUM test for the analysis model of Poland. However, the CUSUM of Squares test for this country indicates a good stability. These deviations are imperceptible as long as the tests on the quality of residuals are congruent with the stability tests. 
Estonia

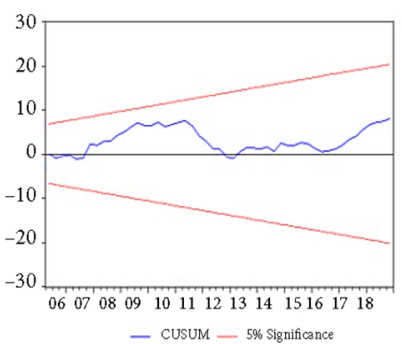

Hungary

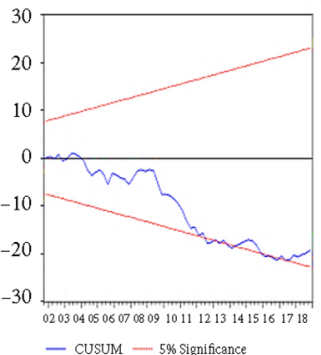

Bulgaria

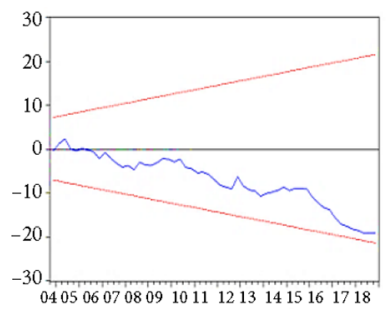

- CUSUM - $5 \%$ significance

Poland

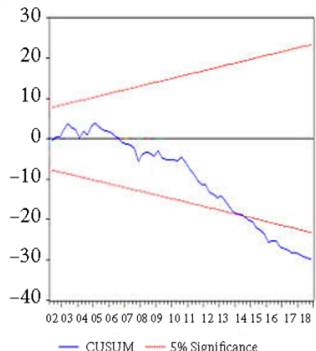

- CUSUM - $5 \%$ Significance
Czech Republic

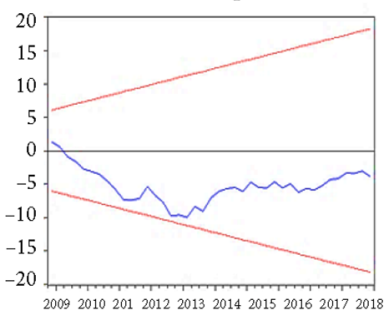

— CUsUM - 5\% significance

Romania
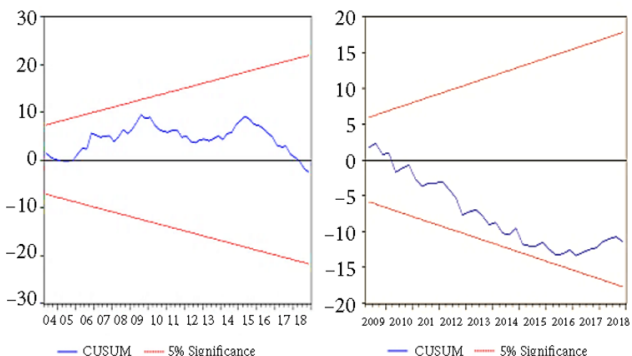

Figure 1. CUSUM Test (source: own data processing)

Estonia

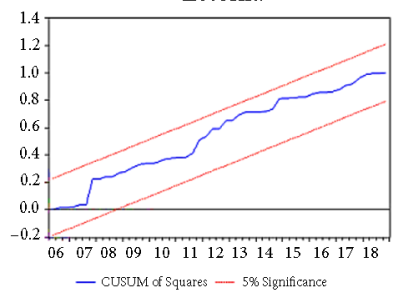

Bulgaria

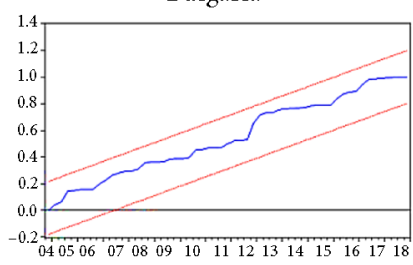

- Cusum of squares - $5 \%$ significance
Czech Republic

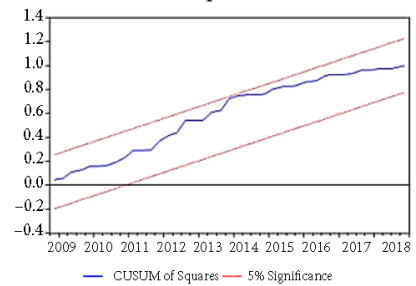

- CusulM of squares - $5 \%$ Significance
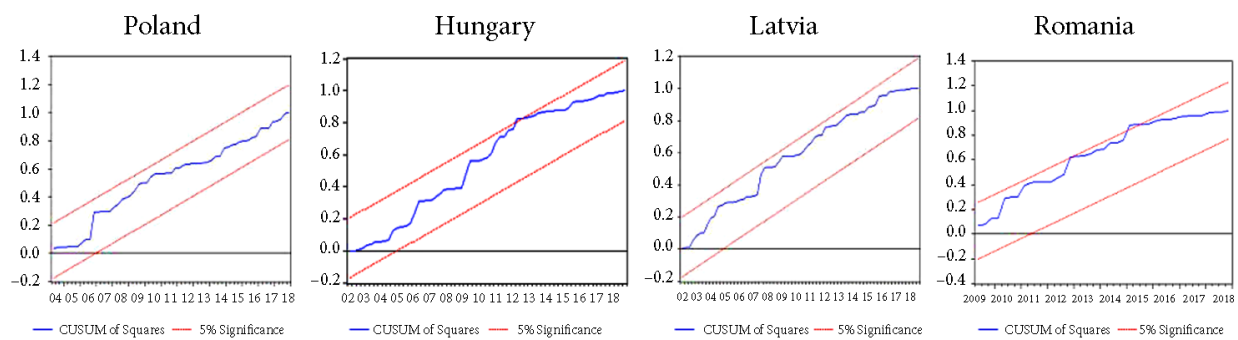

Figure 2. CUSUM of Squares Test (source: own data processing) 


\subsection{Long-run and short-run analysis}

Following the results of the stability tests the models using non-stationary variables were estimated. Robust results were achieved by using the ARDL approach, which allowed the identification of the relationships between the variables both on long-run and short-run. The analysis was initiated by applying the Bound test in order to accept or reject the null hypothesis of lack of cointegration at a significance level of 1\%, 2.5\%, 5\% and $10 \%$. The F-statistic value is compared with the critical values classified in the work of Pesaran et al. (2001). The null hypothesis is rejected if the F-statistic value exceeds the upper limit of the I(1) Bound values, concluding with the existence of cointegration, more precisely by the presence of a long-run relationship between the variables of the model. In most of the countries subjected to the Bound test, the existence of cointegration at a level of $1 \%$ was identified, with the exception of Latvia, for which the null hypothesis was rejected at a level of $2.5 \%$, as well as Hungary at a level of $10 \%$. According to those identified, it can be stated that government expenditure is affected by macroeconomic variables. This assertion is consistent with the study realised by Alexiou (2009) who considered government expenditure being one of the sources of economic instability.

On the contrary, the null hypothesis is accepted if the F-statistic value is positioned below the critical values for $\mathrm{I}(0)$ Bound. The lack of cointegration indicates only the existence of short-run relationships. This aspect was identified in Poland where the F-statistic value of 0.977068 is less than the 1(0) Bound critical value of 2.37 at a significance level of $10 \%$. However, if the F-statistic value is positioned between the lower values of $\mathrm{I}(0)$ Bound and the higher values of I(1) Bound, the test is considered inconclusive, case which was not found in this analysis. Following the application of the Bound test, the long-run coefficients of the ARDL models was estimated. The obtained results are consistent with the economic theory since the signs of the elasticity parameters indicate the interdependence between the variables. A conclusive example can be drawn from the estimation of the long-run coefficients in Romania, since all are statistically representative at a significance level of $1 \%$. Thus, based on Eq. (5), $\beta_{2}=0.759075>0$ the increase in GDP leads to an increase in government expenditure, $\beta_{4}=-0.129042<0$ the increase in government debt leads to decrease in government expenditure and $\beta_{3}=0.496011>0$ the increase in government revenues influences government expenditure in terms of their growth.

The long-run elasticity of the estimated government expenditure has a coefficient of 0.666592 for Bulgaria, respectively 1.162930 for the Czech Republic, being statistically representative at a significance level of $1 \%$. Thus, a previous increase of $1 \%$ of government revenue will derive in a $0.67 \%$ increase in government expenditure in Bulgaria and $1.16 \%$ in the Czech Republic. The GDP is positive and insignificant with a coefficient value of 0.184723 in the case of Bulgaria, and to Czech Republic it is negative and insignificant at a coefficient value of -0.302176 . Moreover, in both countries, government debt does not have significant coefficients. Estonia and Hungary have a relatively similar behaviour in terms of long-run elasticity of government expenditure. As a result, an increase of 1\% in GDP will result in an increase of $1.89 \%$ in government expenditure in Estonia and $1.10 \%$ in Hungary. The previous influence of government debt will have different implications on government expenditure in 
the two countries. The increase of $1 \%$ in government debt will imply a decrease of $0.24 \%$ in government expenditure in Estonia, while in Hungary they will increase by $0.23 \%$. The values of government revenue coefficients will remain negative and insignificant for both countries. The results indicate a positive and insignificant impact of GDP and government revenues on government expenditure in Latvia. The government debt also remains with an insignificant but negative influence on government expenditure. Otherwise, all the coefficients of the long-run estimation are statistically representative at a significance level of $1 \%$ at the level of Romania, respecting the trend of influence found in the other countries under analysis. Thus, the previous increase of $1 \%$ in GDP will derive the current increase of the government expenditure by $0.76 \%$, and the increase with the same percentage of the government revenues will imply their increase by $0.5 \%$. The coefficient of government debt is negative and insignificant at a value of -0.129042 , implying a decrease in government expenditure by $0.13 \%$.

According to the F-statistic value of the Bound test, as well as the long-run elasticity the values of the coefficients obtained in the case of Poland will not be taken into account, as there is only a short-run relationship between the variables subjected to this study. The results of the error - correction estimation indicate the existence of a short-run relationship between the variables of the model presented in Table 2.

According to the analysis, there is no short-run relationship between the government expenditure and GDP at a significance level of 10\% in the Czech Republic and Latvia. The error term, ECM (-1) is negative for each model and statistically representative at a level of 1\%. In Bulgaria and Romania the coefficients of the ECM (-1) term of -1.489369 , respectively -1.326789 , indicate a high rate of convergence to equilibrium. These terms imply that $148.93 \%$ of imbalance of the government expenditure of Bulgaria from the previous period will be adjusted in the current period. In the case of Romania this level is $132.67 \%$. Specifically, it will take almost a quarter to reach the long-run equilibrium. In Czech Republic the ECM ( -1$)$ term is equal to -0.774824 which implies a movement of it with an adjustment speed of $77.48 \%$ towards long-run equilibrium. The short-run dynamics in Estonia is $48.00 \%$, which means that each variable converges to the long-run equilibrium in about two quarters. In Hungary the coefficient of the error correction term is equal to -0.271926 , representing that the government expenditure converges to the long-run equilibrium with an adjustment speed of four quarters. The speed of adjustment in Latvia and Poland is much slower than in the case of the other countries, with ten and seven quarters respectively to reach the long-run equilibrium. Thus, in Latvia the error correction term will adjust $9.64 \%$ of the previous government expenditure imbalance in the current period, and in Poland $14.30 \%$.

Table 2. Error correction representation of the selected ARDL (source: own data processing)

\begin{tabular}{|c|c|c|c|c|}
\hline \multirow{2}{*}{ Country } & Variable & Coefficient & Standard Error & t-Statistic \\
\hline \multirow{3}{*}{ Bulgaria } & $\Delta \mathrm{GDP}$ & -0.849820 & 0.385685 & $-2.203404^{\star *}$ \\
\cline { 2 - 5 } & $\Delta \mathrm{PD}$ & 0.273681 & 0.152395 & $1.795869^{\star * *}$ \\
\cline { 2 - 5 } & $\Delta \mathrm{GR}$ & -0.026561 & 0.131586 & -0.201853 \\
\cline { 2 - 5 } & $\mathrm{ECM}(-1)$ & -1.489369 & 0.186730 & $-7.976050^{\star}$ \\
\hline
\end{tabular}


End of Table 2

\begin{tabular}{|c|c|c|c|c|}
\hline Country & Variable & Coefficient & Standard Error & t-Statistic \\
\hline \multirow{4}{*}{ Czech Republic } & $\Delta \mathrm{GDP}^{\star * * *}$ & & & \\
\hline & $\Delta \mathrm{PD}$ & 0.377010 & 0.107055 & $3.521660^{*}$ \\
\hline & $\Delta \mathrm{GR}$ & 0.728489 & 0.097405 & $7.478990^{*}$ \\
\hline & $\operatorname{ECM}(-1)$ & -0.774824 & 0.100448 & $-7.713699^{*}$ \\
\hline \multirow{4}{*}{ Estonia } & $\Delta \mathrm{GDP}$ & -0.506935 & 0.277195 & $-1.828805^{\star * *}$ \\
\hline & $\Delta \mathrm{PD}$ & -0.022471 & 0.055024 & -0.408392 \\
\hline & $\Delta \mathrm{GR}$ & -0.103042 & 0.074405 & -1.384879 \\
\hline & $\operatorname{ECM}(-1)$ & -0.480004 & 0.076076 & $-6.309566^{*}$ \\
\hline \multirow{4}{*}{ Hungary } & $\Delta \mathrm{GDP}$ & 0.803248 & 0.095032 & $8.452391^{\star}$ \\
\hline & $\Delta \mathrm{PD}$ & 0.226576 & 0.061098 & $3.708407^{\star}$ \\
\hline & $\Delta \mathrm{GR}$ & 0.051515 & 0.060658 & 0.849273 \\
\hline & $\operatorname{ECM}(-1)$ & -0.271926 & 0.061531 & $-4.419318^{\star}$ \\
\hline \multirow{4}{*}{ Latvia } & $\Delta \mathrm{GDP}^{\star * * *}$ & & & \\
\hline & $\Delta \mathrm{PD}$ & -0.007095 & 0.010941 & -0.648433 \\
\hline & $\Delta \mathrm{GR}$ & 0.433626 & 0.082062 & $5.284099^{*}$ \\
\hline & $\operatorname{ECM}(-1)$ & -0.096406 & 0.020088 & $-4.799297^{\star}$ \\
\hline \multirow{4}{*}{ Poland } & $\Delta \mathrm{GDP}$ & 0.594532 & 0.108422 & $5.483501^{\star}$ \\
\hline & $\Delta \mathrm{PD}$ & 0.006932 & 0.005637 & 1.229776 \\
\hline & $\Delta \mathrm{GR}$ & 0.329513 & 0.086193 & $3.822947^{\star}$ \\
\hline & $\operatorname{ECM}(-1)$ & -0.143054 & 0.062872 & $-2.275303^{*}$ \\
\hline \multirow{4}{*}{ Romania } & $\Delta \mathrm{GDP}$ & 0.949600 & 0.199203 & $4.767002^{\star}$ \\
\hline & $\Delta \mathrm{PD}$ & 0.135135 & 0.157501 & 0.857993 \\
\hline & $\Delta \mathrm{GR}$ & 0.098280 & 0.175155 & 0.561106 \\
\hline & $\operatorname{ECM}(-1)$ & -1.326789 & 0.177725 & $-7.465402^{\star}$ \\
\hline
\end{tabular}

Note: ${ }^{*},{ }^{* *},{ }^{* *},{ }^{* * * *}$ represents statistical significance at the $1 \%, 2.5 \%, 5 \%, 10 \%$ level. $\Delta$ represents first difference. $\Delta \mathrm{GE}$ dependent variable.

The results regarding the estimation of the long-run and short-run relationship between the government expenditure and potential output in EU countries obtained by Campeanu and Stoian (2010) are similar to those obtained through this analysis, emphasizing how the countries of Central and Eastern Europe react in the short-run, in order to evaluate the long-run fiscal sustainability. The analysis reveals a harmonization of fiscal sustainability in Bulgaria, Czech Republic, Estonia, Hungary and Latvia, as the level of long-run equilibrium will be easier to achieve. But, for Poland and Romania, sustainable fiscal policy will be more difficult to achieve, and severe fiscal adjustments are required. Furthermore, Arpaia and Turrini (2007) explains that in countries with weak numerical rules for controlling government expenditure, those with small debts or countries with a predominantly aging population, the long-run elasticity is not stable over time, and the average speed of adjustment to the long-run equilibrium of government expenditure is three years, however there are significant differences between countries. 


\subsection{The impulse - response function}

Following the results of the stationarity and cointegration tests, the VECM model was estimated using the variables in first difference, so that the impulse-response functions can be calculated for a period of ten quarters. The impulse-response functions are defined by Alloza (2017) as the evolution of the variables of interest in a specified time horizon after a shock is produced at a given time. Thus, the impulse-response functions were compared in order to evaluate the sustainability of the fiscal policy practiced in the selected countries. In Figure 3 the responses of government expenditure to the shock of exogenous variables were identified. In the VECM panel analysis, the response of government expenditure to the shock of GDP and government revenue remains positive for the entire period analysed, with the exception of the government debt which will have a slightly negative effect towards the end of the determined period. After a positive shock of the GDP, the government expenditure will increase in intensity. The fiscal multiplier has a value of 0.02 in the first period, reaching 0.03 in the third period, and the effect will gradually disappear. The shock produced by government revenue on government expenditure is a positive but not significant. The results obtained are consistent with those highlighted by other authors (Karagyozova-Markova et al., 2013). Szymanska (2018) using a three-variable SVAR model, in accordance with the approach of Blanchard and Perotti (1999), investigated the effects of expenditure shocks for three EEC countries (Czech Republic, Hungary and Poland), the results obtained indicating a positive response in regards to their production. Honda et al. (2020) identified a differentiation of the effects of government spending shocks according to the degree of the countries' development. Baranowski et al. (2016) showed that the government spending multipliers are significantly higher when the output gap is negative. The fiscal multiplier will have a value of 0.01 only during the fourth period of the analysis and with a slight upward trend until the tenth period. The response of government expenditure to government debt will have negative values from the eighth period. However, the value of the fiscal multiplier has values close to zero, which is summed up by an insignificant response of government expenditure to macroeconomic variables. The fiscal multipliers obtained in the panel VECM analysis, are smaller in comparison with the fiscal multipliers obtained in the developed countries. A sustainable development of the economy is more difficult in the selected countries, as government expenditure cannot be used as an automatic stabilizer in fiscal policy.

According to the Cholesky identification scheme, government expenditure is not affected contemporaneously by the changes in real economic activity. In this regard, we suppose that there is no institutional framework for believing that any component of expenditure automatically responds to real changes in activity. From the results obtained
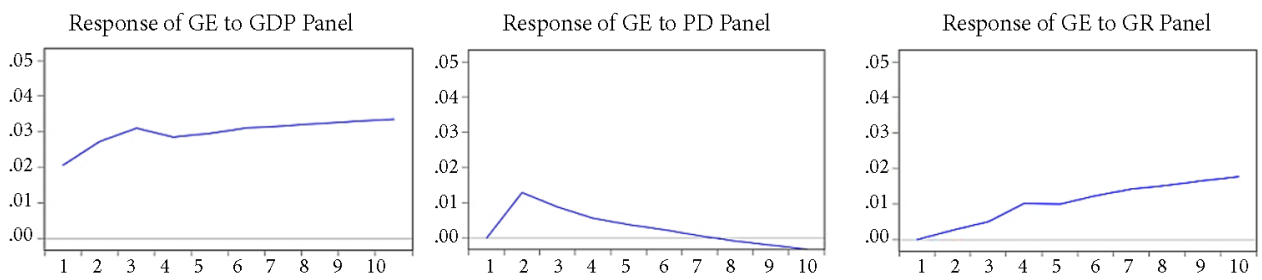

Figure 3. Response to Cholesky One S. D. (d. f. adjusted) Innovations (source: own data processing) 
so far, it was observed that both the shock of the GDP, government revenue and government debt have an asymmetrical impact on the endogenous variable in the short-run and long-run.

The affiliation of these countries, also called satellite countries, to the Eastern bloc, have left a serious mark on the development of their economy. The communist regimes in Eastern Europe collapsed only at the end of 1989, when both Romania and states such as Bulgaria, Hungary or the Czech Republic gained economic sovereignty (Vodă et al., 2020). The late transition to a market economy but also novice fiscal practices are the impediments to the effects of the implementation of fiscal policies focused on the use of government spending as a tool to alleviate shocks.

\section{Conclusions}

Government expenditure is an essential tool in the implementation of fiscal policies regardless of the type of economies or the phases of the business cycle. This paper presented new evidence on the effects of discretionary fiscal policy on the economy in EU countries, based on the structural VAR approach. The main objective of this study was to identify and estimate the long-run elasticity of the government expenditure by observing a similar trend in most of the countries analysed. The previous increase of $1 \%$ in the government revenues derived in a more significant increase of the government expenditure in Bulgaria of $1.16 \%, 0.67 \%$ in Czech Republic and $0.50 \%$ in Romania. Regarding the GDP, its previous increase by $1 \%$ will have more significant effects in the case of Estonia, Hungary and Romania, where the long-run elasticity of government spending will be $1.89 \%, 1.10 \%$ and respectively $0.76 \%$. Contrary to expectations, government debt had no significant influence in any of the analysed countries.

The results of the present study also provide empirical evidence on the rates of convergence to equilibrium, which indicate the period needed to achieve long-run equilibrium. The error-correction estimation indicates the existence of short-run relationships between the variables involved in the analysis. The results revealed that the countries that will have difficulties in reaching the equilibrium are Latvia and Poland, where the short-run dynamics is $9.64 \%$, respectively $14.30 \%$. Thus, it will take about 10 quarters for the two countries to reach the economic equilibrium. At the opposite pole are Bulgaria and Romania, where the coefficients of the ECM (-1) term indicate a convergence rate of $148.93 \%$ and $132.67 \%$, with almost a quarter needed to achieve long-run equilibrium. According to the results of this study, it can be said that government expenditure is moderately affected by macroeconomic variables, and a future analysis for these countries will provide a clearer picture of the dynamics and implications of government expenditure in the implementation of fiscal policies. The robustness of this research has been verified also by estimating the responses of government expenditure to the shock of the gross domestic product, government revenues and government debt in the analysed countries, based on the Cholesky recursive approach. The economic modelling transposes the chosen hypotheses in quantitative language through the economic models which can be used to predict the variables of interest. According to the impulse-response functions we can mention the fact that the dynamics of the variables 
in the panel type VECM model outlines a realistic image that still exists today. Government expenditure has shown a weak response to fiscal shocks, fiscal multipliers are both positive and negative but their values are small, meaning that economic activity is not significantly influenced by fiscal policies in the analysed countries. Causal relationship between the variables cannot be explained because their value is small and in order to explain to what extent an economic impulse influences an explanatory measure, the value of the fiscal multiplier must be greater than one. The study allowed the validation of the two hypotheses by using scientific methods and techniques. Although government spending plays a strategic role in implementing fiscal policy and ensuring long-term fiscal sustainability, due to the geopolitical context in Eastern European countries, its effect cannot be identified as a constituent part of the relief of fiscal shocks. Moreover, the second hypothesis regarding the applicability of the fiscal policy and its effects of ameliorating the shocks is supported by the very value of the tax multipliers which is almost zero. Thus, a percentage change in the variables involved in the analysis does not produce economic balancing effects. The reaction of economic agents to fiscal incentives is only positive if they cause a long-term income growth. Consequently, the application of volatile fiscal policies can have negative effects on the economic environment, production and social welfare. It is necessary to adopt a fiscal policy that provide support for the development of the small and medium enterprises, and can reduce the fiscal burden from the state on the businesses. It is also important to exercise fiscal policy in macroeconomic terms in relation to the state of the business cycle. The research carried out is not exhaustive, presenting certain limitations. Thus, the marginal inclination towards saving, which can negatively influence the size of the fiscal multipliers, has not been taken into account. Future directions may aim to identify the factors that support the process of implementing some counter-cyclical policies, so as to ensure both a coherence between the strategic development objectives and the stages of the economic cycle and the strengthening of fiscal-budgetary governance. Also, a study on consumption, number of hours worked, production and private investments made in correlation with the adopted fiscal measures would be useful.

\section{Author contributions}

GD and ADV conceived the study and were responsible for the design and development of the data analysis. GD, ADV and DDD were responsible for data collection and analysis. GD and AVD were responsible for data interpretation. ADV wrote the first draft of the article; DDD was responsible for resources, visualization and validation.

\section{Disclosure statement}

We declare that we don't have any competing financial, professional, or personal interests from other parties. 


\section{References}

Aderemi, T. A., Akinwande, S. A., Olayemi, H. O., \& Omogboye, M. A. (2019). Impact of monetary policy on exchange rate in Nigeria: Bound test and ARDL approach. Acta Universitatis Danubius (Economica), 15(4), 234-243.

http://journals.univ-danubius.ro/index.php/oeconomica/article/view/5527

Afonso, A., \& Leal, F. S. (2019). Fiscal multipliers in the Eurozone: An SVAR analysis. Applied Economics, 51(51), 5577-5593. https://doi.org/10.1080/00036846.2019.1616068

Afonso, A., \& Sousa, R. (2009, January). The Macroeconomic effects of fiscal policy (ECB Working Paper series, No. 991). European Central Bank. https://www.ecb.europa.eu/pub/pdf/scpwps/ecbwp991.pdf

Akerlof, G., Blanchard, O., Romer, D., \& Stiglitz, J. (2014). What have we learned: Macroeconomic policy after the crisis. MIT Press. http://www.jstor.org/stable/j.ctt9qf899

Alexiou, C. (2009). Government spending and economic growth: Econometric evidence from the South Eastern Europe (SEE). Journal of Economic and Social Research, 11(1), 1-16.

https://www.researchgate.net/publication/228647975_Government_Spending_and_Economic_ Growth_Econometric_Evidence_from_the_South_Eastern_Europe_SEE

Alloza, M. (2017). A very short note on computing impulse response functions. University College, London. http://www.ucl.ac.uk/ uctp041/Teaching_files/Tutorial_IRF.pdf

Anzuini, A., Rossi, L., \& Tommasino, P. (2020, September). Fiscal policy uncertainty and the business cycle: Time series evidence from Italy. Journal of Macroeconomics, 65, 103238. https://doi.org/10.1016/j.jmacro.2020.103238

Arnold, J. M., Brys, B., Heady, C., Johansson, A., Shwellius, C., \& Vartia, L. (2011). Tax policy for economic growth. The Economic Journal, 121(550), F59-F80. https://doi.org/10.1111/j.1468-0297.2010.02415.x

Arpaia, A., \& Turrini, A. (2007, March 29). Government expenditure and economic growth in the EU: Long-run tendencies and short-term adjustment.

https://papers.ssrn.com/sol3/papers.cfm?abstract_id=2004461

Ban, C. (2014). Austerity versus Stimulus? Understanding fiscal policy change at the International Monetary Fund since the Great Recession. Governance, 28(2), 167-183.

https://doi.org/10.1111/gove.12099

Baranowski, P., Krajewski, P., Mackiewicz, M., \& Szymańska, A. (2016). The effectiveness of fiscal policy over the business cycle: A CEE perspective. Emerging Markets Finance and Trade, 52(8), 1910-1921. https://doi.org/10.1080/1540496X.2015.1046335

Benkwitz, A., Lütkepohl, H., \& Wolters, J. (2001). Comparison of bootstrap confidence intervals for impulse responses of German monetary systems. Macroeconomic Dynamics, 5(1), 81-100. https://doi.org/10.1017/S1365100501018041

Bhandari, A., Evans, D., Golosov, M., \& Sargent, T. J. (2017). Fiscal policy and debt management with incomplete markets. The Quarterly Journal of Economics, 132(2), 617-663.

https://doi.org/10.1093/qje/qjw041

Blanchard, O., \& Perotti, R. (1999). An empirical characterization of the dynamic effects of changes in government spending and taxes on output (NBER Working Paper, 7269). National Bureau of Economic Research. https://doi.org/10.3386/w7269

Blinder, A. S. (2017). Keynesian economics. Concise encyclopedia of economics. Library of Economics and Liberty. https://www.econlib.org/library/Enc/KeynesianEconomics.html

Bodea, C., \& Higashijima, M. (2017). Central Bank independence and fiscal policy: Can the Central Bank restrain deficit spending? British Journal of Political Science, 47(1), 47-70.

https://doi.org/10.1017/S0007123415000058 
Boiciuc, I. (2015). The effects of fiscal policy shocks in Romania. A SVAR Approach. Procedia Economics and Finance, 32, 1131-1139. https://doi.org/10.1016/S2212-5671(15)01578-6

Bova, E., Carcenac, N., \& Guerguil, M. (2014, July 10). Fiscal rules and the procyclicality of fiscal policy in the developing world (IMF Working Paper, 2014/122). International Monetary Fund. https://doi.org/10.5089/9781498305525.001

Bwire, T., Lloyd, T., \& Morrissey, O. (2017). Fiscal reforms and the fiscal effects aid in Uganda. The Journal of Development Studies, 53(7), 1019-1036. https://doi.org/10.1080/00220388.2017.1303677

Campeanu, E., \& Stoian, A. (2010). Fiscal policy reaction in the short term for assessing fiscal sustainability in the long runin Central and Eastern European countries. Czech Journal of Economics and Finance (Finance a uver), 60(6), 501-518.

https://ideas.repec.org/a/fau/fauart/v60y2010i6p501-518.html

Cavaliere, G., Rahbek, A., \& Taylor, A. R. (2012). Bootstrap determination of the co-integration rank in vector autoregressive models. Econometrica, 80(4), 1721-1740. https://doi.org/10.3982/ECTA9099

Creswell, J. W., \& Plano Clark, V. L. (2017, September). Designing and conducting mixed methods research ( $3^{\text {rd }}$ ed.). Sage publications. https://us.sagepub.com/en-us/nam/designing-and-conductingmixed-methods-research/book241842\#resources

Downs, A. (1957). An economic theory of democracy ( $1^{\text {st }}$ ed.). Harper \& Row Publisher. https://www.amazon.com/Economic-Theory-Democracy-Anthony-Downs/dp/0060417501

Engle, R. F., \& Granger, C. W. (1987). Co-integration and error correction: representation, estimation, and testing. Econometrica, 55(2), 251-276. https://doi.org/10.2307/1913236

Ferede, E., \& Dahlby, B. (2016). Cutting provincial corporate income tax rates to promote investment, employment and economic growth. SPP Research Paper, 8(8), 1-6. https://www.policyschool.ca/ wp-content/uploads/2016/05/cutting-provincial-cits-ferede-dahlby.pdf

Gadatsch, N., Hauzenberger, K., \& Stähler, N. (2016). Fiscal policy during the crisis: A look on Germany and the Euro area with GEAR. Economic Modelling, 52(Part B), 997-1016. https://doi.org/10.1016/j.econmod.2015.10.038

Gechert, S. (2015). What fiscal policy is most effective? A meta-regression analysis. Oxford Economic Papers, 67(3), 553-580. https://doi.org/10.1093/oep/gpv027

Golinelli, R., Mammi, I., \& Musolesi, A. (2018, April 24). Parameter heterogeneity, persistence and crosssectional dependence: New insights on fiscal policy reaction functions for the Euro Area (Quaderni Working Paper DSE, 1120). https://doi.org/10.2139/ssrn.3156879

Gonzalo, J. (1994). Five alternative methods of estimating long-run equilibrium relationships. Journal of Econometrics, 60(1-2), 203-233. https://doi.org/10.1016/0304-4076(94)90044-2

Hamilton, J. D. (1994). Time series analysis (Vol. 2, pp. 690-696). Princeton University Press.

Heinemann, F., Moessinger, M., D., \& Yeter, M. (2018). Do fiscal rules constrain fiscal policy? A metaregression-analysis. European Journal of Political Economy, 51, 69-92.

https://doi.org/10.1016/j.ejpoleco.2017.03.008

Honda, J., Miyamoto, H., \& Taniguchi, M. (2020, January). Exploring the output effect of fiscal policy shocks in low income countries (IMF Working Paper No. 20/12). https://doi.org/10.5089/9781513526034.001

Johannsen, B. K. (2014, May 22). When are the effects of fiscal policy uncertainty large? (Finance and Economics Discussion Series (FEDS) 2014-40).

https://www.federalreserve.gov/pubs/feds/2014/201440/201440pap.pdf

Johansen, S. (1988). Statistical analysis of cointegration vectors. Journal of Economic Dynamics and Control, 12(2-3), 231-254. https://doi.org/10.1016/0165-1889(88)90041-3

Johansen, S. (1991). Estimation and hypothesis testing of cointegration vectors in Gaussian vector autoregressive models. Econometrica, 59(6), 1551-1580. https://doi.org/10.2307/2938278 
Jordà, Ò., \& Taylor, A. M. (2015). The time for austerity: Estimating the average treatment effect of fiscal policy. The Economic Journal, 126(590), 219-255. https://doi.org/10.1111/ecoj.12332

Karagyozova-Markova, K., Deyanov, G., \& Iliev, V. (2013, December). Fiscal policy and economic growth in Bulgaria (Discussion papers DP/90/2013). Bulgarian National Bank. https://www.bnb.bg/bnbweb/ groups/public/documents/bnb_publication/discussion_2013_90_en.pdf

Leeper, E. M. (2017, July). Monetary-fiscal policy interactions. Testimony before the subcommittee on monetary policy and trade committee on financial services. U.S. House of Representatives. https://financialservices.house.gov/uploadedfiles/07.20.2017_eric_leeper_testimony.pdf

Liew, V. K. S. (2004). Which lag length selection criteria should we employ? Economics Bulletin, 3(33), 1-9. https://econpapers.repec.org/article/eblecbull/eb-04c20021.htm

Mertens, K. R. S. M., \& Ravn, M. (2014). Fiscal policy in an expectations-driven liquidity trap. The Review of Economic Studies, 81(4), 1637-1667. https://doi.org/10.1093/restud/rdu016

Mirdala, R. (2009, October). Effects of fiscal policy shocks in the European transition economies (MPRA Paper 19481). https://mpra.ub.uni-muenchen.de/19481/1/MPRA_paper_19481.pdf

Munir, K., \& Riaz, N. (2019, May). Macroeconomic effects of foscal policy in Pakistan: A disaggregate analysis. Applied Economics, 51(52), 5652-5662. https://doi.org/10.1080/00036846.2019.1616074

O'Sullivan, A., \& Sheffrin, S. M. (2003). Economics: Principles in action. Upper Saddle River. Prentice Hall. https://www.worldcat.org/title/economics-principles-in-action/oclc/50237774

Özer, M., \& Karagöl, V. (2018). Relative effectiveness of monetary and fiscal policies on output growth in Turkey: an ARDL bounds test approach. Equilibrium. Quarterly Journal of Economics and Economic Policy, 13(3), 391-409. https://doi.org/10.24136/eq.2018.019

Palley, T. I. (2015). Money, fiscal policy, and interest rates: A critique of modern monetary theory. Review of Political Economy, 27(1), 1-23. https://doi.org/10.1080/09538259.2014.957466

Peren Arin, K., Braunfels, E., \& Doppelhofer, G. (2019, December). Revisiting the growth effects of fiscal policy: A Bayesian model averaging approach. Journal of Macroeconomics, 62, 103158. https://doi.org/10.1016/j.jmacro.2019.103158

Perotti, R. (2004, December). Estimating the effects of fiscal policy in OECD countries (IGIER Working Paper 276). https://doi.org/10.2139/ssrn.637189

Pesaran, M. H., \& Shin, Y. (1998). An autoregressive distributed-lag modelling approach to cointegration analysis. Econometric Society Monographs, 31, 371-413.

Pesaran, M. H., Shin, Y., \& Smith, R. J. (2001) Bounds testing approaches to the analysis of level relationships. Journal of Applied Econometrics, 16(3), 289-326. https://doi.org/10.1002/jae.616

Pontus, R. (2016). Fiscal policy in an unemployment crisis. The Review of Economic Studies, 83(3), 1189-1224. https://doi.org/10.1093/restud/rdv058

Romer, D. (2011, March). What have we learned about fiscal policy from the crisis. In International Monetary Fund Conference on Macro and Growth Policies in the Wake of the Crisis. https://www.imf.org/external/np/seminars/eng/2011/res/pdf/DR3presentation.pdf

Salto, M. (2016, July). Fiscal policy after the crisis - Workshop Proceedings (Discussion Paper 35). European Comission. https://ec.europa.eu/info/publications/economy-finance/fiscal-policy-after-crisisworkshop-proceedings_en

Stockhammer, E., Qazizada, W., \& Gechert, S. (2016, April). Demand effects of fiscal policy since 2008 (Working Paper No. 1607). Post Keynesian Economics Study Group. http://www.postkeynesian.net/downloads/working-papers/PKWP1607.pdf

Szymanska, A. (2018). Comparison of the stabilizing effects of government spending shocks in the Czech Republic, Hungary and Poland. Economic Research, 32(1), 2899-2923.

https://doi.org/10.1080/1331677X.2019.1653783 
Tabellini, G. (2016, April). Building common fiscal policy in the Eurozone. In R. Baldwin \& F. Giavazzi (Eds.), How to fix Europe's monetary union: Views of leading economists. CEPR Press. https://voxeu.org/article/building-common-fiscal-policy-eurozone

Cordes, T., Kinda, T., Muthoora, P., \& Weber, A. (2015, February). Expenditure rules: Effective tools for sound fiscal policy? (IMF Working Paper, 2015/29). International Monetary Fund. https://doi.org/10.5089/9781498390576.001

Teles, V. K., \& Mussolini, C. (2014). Public debt and the limits of fiscal policy to increase economic growth. European Economic Review, 66, 1-15. https://doi.org/10.1016/j.euroecorev.2013.11.003

Usman, M., Fatin, D. F., Barusman, M. Y. S., \& Elfaki, F. A. (2017). Application of Vector Error Correction Model (VECM) and impulse response function for analysis data index of farmers' terms of trade. Indian Journal of Science and Technology, 10(19), 1-14. https://doi.org/10.17485/ijst/2017/v10i19/112258

Vodă, A. D., Dobrotă, G., Cristea, L. A., \& Ciocanea, B. (2020). Do fiscal rules constrain fiscal policy in Romania? KnE Social Sciences, 4(1), 17-33. https://doi.org/10.18502/kss.v4i1.5975 